\title{
Panca Pramana Cycle-Based Science Learning Model for Promoting 21st Century Skills Learning
}

\author{
I Gede Astawan ${ }^{1 *}$, Nice Maylani Asril ${ }^{1}$, Luh Ayu Tirtayani ${ }^{1}$, Ni Wayan Surya \\ Mahayanti $^{1}$, Kadek Eva Khrisna Adnyani ${ }^{1}$, I Ketut Resika Arthana ${ }^{1}$ \\ ${ }^{1}$ Universitas Pendidikan Ganesha, Indonesia \\ ${ }^{*}$ Corresponding author. Email: astawan@undiksha.ac.id
}

\begin{abstract}
This study aimed to analyze the needs to develop a science learning model based on the Panca Pramana learning cycle to improve the 21st-century skills of elementary school student teachers (PGSD). The study population was PGSD students and PGSD lecturers who taught science courses. Through purposive sampling, 107 students and 9 lecturers were recruited. The method used in this research is a survey study by distributing questionnaires. The results showed that developing a science learning model based on the Panca Pramana learning cycle is needed in designing meaningful learning for students, especially in improving 21st-century skills. The average score of students' responses about local wisdom learning development was 80.61 in the excellent category. The lecturers' average score regarding developing the Panca Pramana learning model was 88.89 in the outstanding category. It indicates that students and lecturers support developing a science learning model based on the Panca Pramana learning cycle.
\end{abstract}

Keywords: Science Learning Model, Local Wisdom, Panca Pramana, 21st-Century Skills

\section{INTRODUCTION}

Education is closely related to culture. This can be seen from the function of education, which is empowering human potential to bequeath, build, and develop future cultures and civilizations [1]. Until now, the implementation of science education in Indonesia tends to be adopted from western culture. The science curriculum applied in formal schools, ranging from kindergarten, elementary school to university is adopted based on western culture. This shows the dependence of the Indonesian nation in science education [2]. As a result of the educational practice of adopting the education of western culture, which is not necessarily compatible with the nation's own cultural pattern, has proven successful in forming a generation that is hedonistic, consumptive, proud of outside products, and do not feel confidence with domestic products. Other implications can be seen from the low quality of education in Indonesia. The UNDP report reveals that the Human Development Index (HDI) in 2019 ranked Indonesia 111th out of 189 countries [3].
Meanwhile, the skills that students need to learn in order to survive are 21 st century skills. 21 st century skills become a necessity for everyone to be able to survive the dynamics of life in the digital era [4][5]. 21st century skills are not only needed in relation to increase one's academic capacity, but are also needed in the development of aspects of attitudes and characters.

Based on preliminary studies conducted on science learning both in elementary schools and in PGSD departments as a graduate developer of prospective elementary teachers, shows that (1) learning has not been focused on equipping students to have 21 st century skills; (2) science learning has not implemented a local culturebased learning model; (3) the tools used in supporting learning have not integrated local culture; (4) the evaluation used has not been oriented to local wisdom values; (5) the scope of science studies in elementary school and PGSD is very relevant to be integrated with local culture [6][7][5]. This condition, in line with the results of Suja's research, revealed that there has not been much science learning utilizing the potential of indigenous Balinese science[6]. According to [8], the integration of local culture is very helpful for learners to 
understand their own culture and has implications for better achievement. The integration of original science can be done in a hidden curriculum. Similar research was also conducted by Subagia and Wiratma (2007), Suja, et al.(2009), and Sukadi (2013) revealed that teachers in Bali have not used much pedagogical-based learning based on local culture[9] [10] [11]. The learning in elementary school in Bali refer more to the culture that comes from the west.

The researches of Balinese culture-based learning models developed have not been oriented towards improving the skills of the 21 st century. In addition, in the learning syntax, the models explicitly do not have the stages of formulation of hypotheses. Meanwhile, in this study the learning model developed was oriented to facilitate students to learn to have 21 st century skills. One of the syntax added to the learning model to be developed is the formulation of hypotheses (arthapati pramana). Thus, there are five components of learning syntax used, including sabda pramana, anumana pramana, upamana pramana, arthapati pramana, and pratyaksa pramana. This is in line with the statement of Suja, et al. which states that the more ways used to gain knowledge, the stronger the learner's understanding of the object he is studying [10].

Departing from these problems, especially with regard to the low skills of 21 st century learners, it becomes very urgent to immediately look for solutions. In this case, the real solution offered is related to the provision of the right learning model to facilitate learners learning. The solution that is seen as appropriate to overcome the problem of low skills of 21 st century learners is through the development of science learning models based on panca pramana. Panca pramana is a traditional way of learning that has been described in one of the branches of Hindu philosophy (nawa darsana), namely mimamsa darsana [12].

\section{METHOD}

Analysis of the needs of the development of this learning model based on local wisdom of trikaya parisudha and local culture of Balinese people. This development research used survey method [13]. Survey method is used to get responses from respondents about the need for product development according to the needs. Basic needs analysis is derived from data on (1) student responses on 21 st century skills, science learning at PGSD, and local learning development efforts; (2) lecturers' responses about 21st century skills, local wisdom of panca pramana, about the science learning model used, and efforts to develop the learning model of panca pramana. The populations of this research were students and lecturers of PGSD lecturing science courses. Sampling of research was determined by purposive sampling technique. The sample of students was 107 people. Meanwhile, the lecturers were 9 people. The research data was collected using questionnaires. To analyze the research data used descriptive analysis techniques.

\section{RESULTS}

Responses from 107 students about 21 st century skills were selected in 8 items of questionnaires. Each item uses a scale of $1-4$, so the highest raw score is 32 and the lowest is 8 . The raw score obtained by the student is transformed to a scale of $0-100$. The results showed that students' responses to 21 st century skills were sufficient $(\mathrm{M}=69.45 ; \mathrm{SD}=6.47)$. This response indicates that the development of local learning models provides meaningful learning opportunities for students in order to improve 21 st century skills with better quality.

Responses were from 107 students about science learning with four questionnaires. Each item used a scale of $1-4$, so the highest raw score is 16 and the lowest is 4 . The raw score obtained by the student is transformed to a scale of $0-100$. The results showed that students' responses about science learning were categorized as sufficient $(M=69.22 ; \mathrm{SD}=7.90)$. This response indicates that the development of local learning models provides meaningful learning opportunities for students in order to improve 21 st century skills with better quality.

The response from 107 students about the development of local learning was selected in four questionnaires. Each item used a scale of 1-4, so the highest raw score is 16 and the lowest is 4 . The raw score obtained by the student is transformed to a scale of 0-100. The results showed that students' responses about the development of local wisdom learning were categorized as Good $(\mathrm{M}=80.61 ; \mathrm{SD}=10.37)$. This response indicates that students support efforts to develop local learning models in order to improve 21 st century skills with better quality.

Responses from nine lecturers about 21st century skills were selected in 6 rounds of questionnaires. Each item used a scale of $1-4$, so the highest raw score is 24 and the lowest is 6 .The raw score obtained by the lecturer was transformed to a scale of $0-100$. The results showed that lecturers' responses to 21st century skills were categorized as Good $(\mathrm{M}=83.80 ; \mathrm{SD}=11.87)$. This response indicates that the development of local learning models provides meaningful learning opportunities for lecturers in order to improve 21 st century skills with better quality.

Responses from nine lecturers about local wisdom of panca pramana were selected in 13 items of questionnaire. Each item used a scale of 1-4, so the highest raw score was 52 and the lowest was 13 . The raw score obtained by the lecturer was transformed to a scale of 0-100. The results showed that the lecturer's response about local wisdom of panca pramana was categorized Very Good $(\mathrm{M}=86,54 ; \mathrm{SD}=12.68)$. This response 
indicates that the development of local learning models provides meaningful learning opportunities for lecturers in order to improve 21 st century skills with better quality.

The responses from nine lecturers about science learning model were selected in 4 questionnaires. Each item used a scale of 1-4, so the highest raw score was 16 and the lowest was 4 . The raw score obtained by the lecturer was transformed to a scale of 0-100. The results showed that lecturers' responses about science learning models were categorized as Low $(\mathrm{M}=50.69$; $\mathrm{SD}=$ 25.47). This response indicates that the learning model has not yet integrated local wisdom. This means to develop a local learning model.

The responses from nine lecturers about the development of the learning model of panca pramana were selected in 3 questionnaires. Each item used a scale of $1-4$, so the highest raw score was 12 and the lowest was 3.The raw score obtained by the lecturer was transformed to a scale of 0-100. The results showed that the lecturer's response about the efforts to develop the panca pramana learning model was categorized very good $(\mathrm{M}=88.89 ; \mathrm{SD}=13.18)$. This response indicates that the development of local learning models received a positive response.

\section{DISCUSSION}

Learners have the view that science learning is boring, because it is taught similarly to historical learning delivered conventionally through lecture methods. The results of research conducted by Suciati, revealed that elementary school students often complain and are disappointed to learn science [14]. Surya states that students are less interested in learning science because science lessons are full of mathematical formulas [15]. The negative perception of the students has a direct effect on the achievement of students' learning outcomes, which tend to be low. The factors thought to be the cause are that science learning tends to focus on mathematical aspects, a little emphasis on concepts and principles, and no planting of character values [16]. Science learning is less meaningful because it does not associate content with context, so science learning seems unrelated to everyday life. Suja in his research concluded that the use of western science is only in school environments and not functional in people's lives[6]. In other words, science learning does not accommodate the original science (local) that becomes the local wisdom of the community. This happens because of two things, namely (1) the learning model used has not used local cultural wisdom as a learning base, and (2) the learning tools used, such as books, Student Worksheets (LKPD), and Lesson Plan (RPP) tend to be general only containing concepts and principles, not yet integrating local cultural wisdom. The statement, supported by survey results that from 12 elementary school teachers, to date the learning model and devices used have not integrated local culture and wisdom.

The results of observations on learning tools used by educators revealed that books, LKPD, and RPP tend not to be based on the values of local cultural wisdom. It is suspected that educators have not internalized, both local wisdom and local culture, so that it becomes an obstacle in designing and implementing learning based on local cultural wisdom. The statement is supported by survey results that state that their understanding of the integration of local cultural wisdom is sufficient. These findings indicate the importance of researching the development of learning models based on local cultural wisdom.

Research on the topic of developing learning models based on local cultural wisdom has been widely done by researchers before. Subagia and Wiratma in their research revealed that tri pramana based learning cycle models is effectively improve the quality of science learning in elementary, junior high school and senior high school [17]. The quality of science learning includes: (1) student learning activities, (2) student learning creativity, (3) effectiveness of learning, and (4) a pleasant learning atmosphere. Suja, et al. also conducted similar research, revealing that learning cycle models of catur pramana is effective to be used to improve the quality of processes, learning outcomes, and scientific attitudes of high school students in Singaraja City [10]. Research related to Balinese culture was also conducted by Suastra and Tika [1]. The findings of the study concluded that the local culture-based science learning model can develop basic competencies of science and the value of local wisdom of State Junior High Shcool in Singaraja City. The basic competencies of science being developed include scientific performance and achievement of science learning achievement. There are four values of local wisdom developed, namely (1) the value of harmony, (2) the value of preservation / nature, (3) holistic values, and (4) local traditions.

Alexon and Sukmadinata in their research concluded that the integrated culture-based learning model proved to be significantly effective in enhancing students' appreciation of SD in Bengkulu City towards local culture and mastery of learning materials simultaneously [18]. Sukadi conducted development research related to Balinese culture revealed some conclusions [11]. First, the implementation of PKn learning model as a category of PKn learning as yadnya gives the category of learning achievement for grade 6 elementary school students in Bali Province is sufficient in terms of citizenship knowledge, high category on the orientation aspect of citizenship value, and high categories on aspects of civic behavior. Second, the implementation of PKn learning model as a method of PKn learning as yadnya significantly affecting students' PKn learning outcomes 
on aspects of knowledge, value orientation, and civilization behavior simultaneously.

Suja's research revealed that the use of junior high school science textbooks by integrating the content and context of Balinese cultural pedagogy can improve students' learning activities and outcomes [6]. Students' response to learning is very positive. Furthermore, Suja developed research on the development of science textbooks in elementary school containing Balinese cultural pedagogy [2]. The findings of the research revealed that (1) all basic science competency standards and $99.16 \%$ of basic strategic competencies are taught with the learning cycle of Catur Pramana; (2) relevant original science concepts are integrated into science curriculum of elementary School, including: local wisdom on environmental arrangement, animal classification, health maintenance, utilization of material properties for the manufacture of traditional tools, conception of space and time of Balinese people, as well as energy use and savings; and (3) the supporting capacity of human resources and learning facilities still needs to be improved for the application of Science learning containing original science content and pedagogy context of catur pramana.

Subagia and Wiratma in their research concluded that the application of tri pramana learning cycle model is able to improve the quality of student learning processes and outcomes [17]. The model can realize student centered learning. Furthermore, Subagia and Wiratma develop learning taxonomy and assessment of trikayabased learning outcomes [19]. The findings of the research revealed that taxonomy trikaya consists of three domains, namely the domain of the mind (manacika), words (wacika), and deeds (kayika). Domains of mind consist of: 1) factual thinking, 2) positive thinking, 3) logical rational thinking, 4) critical thinking, and 5) innovative creative thinking. Domain of words: 1) speaking politely, 2) speaking factually, 3) speaking logical rationale, 4) speaking systematically, and 5) communicative speaking. Domain of deeds consist of: 1) be polite, 2) be obedient, 3) be honest, 4) be confident, and 5) be creatively innovative.

Based on the description above, the development of science learning model based on local wisdom is very important and worth doing. This is strongly supported by PGSD students and lecturers, that they strongly support the development plan of learning model that makes local wisdom and culture as the basis of learning.

The findings of this study have implications that it is important for educators to integrate local wisdom in learning. Science learning models based on the learning cycle of panca pramana is good to be developed. Learning objectives need to be developed to equip students with 21 st century skills.

\section{CONCLUSION}

Based on the results of research and discussion, it can be concluded that the development of science learning models based on the learning cycle of panca pramana to improve students' skills of 21 st century is important. The average score of student responses about local learning development was 80.61 in the good category. The average score of lecturers' responses about the development efforts of the panca pramana learning model of 88.89 falls in the category of very good. This indicates that students and lecturers do support efforts to develop science learning models based on this panca pramana learning cycle.

To policyholders, it is recommended to make local wisdom as the basis of learning carried out by lecturers / teachers. Local wisdom can be used as a bridge between local knowledge owned by children with scientific knowledge that has been proven to be true. To lecturers/ teachers, it is recommended that the applied learning not only equips children with knowledge, but also develops 21 st century skills, namely critical thinking, creative thinking, communication and collaboration.

\section{REFERENCES}

[1] I. W. Suastra, K. Tika, N. Kariasa, Efektivitas Model Pembelajaran Sains Berbasis Budaya Lokal Untuk Mengembangkan Kompetensi Dasar Sains dan Nilai Kearifan Lokal di SMP, J. Penelit. Dan Pengemb. Pendidik. vol. 5, 2011, pp. 258-273.

[2] I. W. Suja, Analisis Kebutuhan Pengembangan Buku Ajar Sains SD Bermuatan Pedagogi Budaya Bali, J. Pendidik. dan Pengajaran. vol. 44, 2011, pp. 84-92.

[3] UNDP, ed., Sustaining human progress: reducing vulnerabilities and building resilience, United Nations Development Programme, New York, NY, 2014. http://hdr.undp.org/sites/default/files/hdr14report-en-1.pdf.

[4] S. Zubaidah, Keterampilan Abad Ke-21: Keterampilan yang Diajarkan Melalui Pembelajaran, Semin. Nas. Pendidik. dengan Tema Isu-isu Strateg. Pembelajaran MIPA Abad 21, 2016, pp. 1-17.

[5] I. G. Astawan, D. N. Sudana, N. Kusmariyatni, I. G. Ngurah, The STEAM Integrated Panca Pramana Model in Learning Elementary School Science in The Industrial Revolution Era 4.0, Int. J. Innov. vol. 5, 2019, pp. 26-39.

[6] I. W. Suja, Pengembangan Buku Ajar Sains SMP Mengintegrasikan Content dan Context Pedagogi Budaya Bali, J. Pendidik. dan Pengajaran. vol. 43, 2010, pp. 79-88. 
[7] I. W. Suastra, Model Pembelajaran Sains Berbasis Budaya Lokal Untuk Mengembangkan Kompetensi Dasar Sains dan Nilai Kearifan Lokal di SMP, J. Pendidik dan Pengajaran, vol. 43, 2010, pp. 8-19.

[8] K. Rahman, Belonging and Learning to Belong in School: the Implications of the Hidden Curriculum for Indigenous Students, Discourse Stud. Cult. Polit. Educ. vol. 34, 2013, pp. 660-672. DOI: https://doi.org/10.1080/01596306.2013.728362.

[9] I. W. Subagia, I.G.L. Wiratma, Potret Pelaksanaan Pembelajaran Sains pada Berbagai Jenjang Sekolah di Bali, J. Pendidik dan Pembelajaran JPP. vol. 14, 2009.

[10] I. W. Suja, F. Nurlita, N. Retug, Pengembangan Model Pembelajaran Kimia Berbasis Siklus Belajar Catur Pramana, J. Pendidik dan Pengajaran, vol. 42, 2009, pp. 30-36.

[11] S. Sukadi, Belajar dan Pembelajaran Pkn SD sebagai Yadnya dalam Rangka Perwujudan Dharma Agama dan Dharma Negara Berbasis Konstruktivisme, Cakrawala Pendidik, 2013, pp. 196-206.

[12] I. K. Seregig, Nawa Darsana 9 Sistem Filsafat Hindu, Paramita, Surabaya, 2012.

[13] M. D. Gall, W. R. Borg, Educational Research: an Introduction (7th ed.), 7th ed., Longman, Inc, New York, 2003.

[14] N. W. Suciati, Pengaruh Pembelajaran Kontekstual Berbasis Asesmen Fortofolio dan Motivasi Berprestasi Terhadap Prestasi Belajar Siswa (Studi pada Sekolah Dasar No. 1 dan 3 Lukluk, Kecamatan Mengwi), Program Pascasarjana, Universitas Pendidikan Ganesha, 2009.

[15] Y. Surya, Fisika Gasing: Gampang, Asyik \& Menyenangkan, Surya Institute, Jakarta, 2008.

[16] I. W. Santyasa, I. W. Suastwa, I. G. Astawan, Pengembangan Buku Ajar dan Perangkat Pembelajaran Fisiska SMA Berbasis Model-Model Student Centered Learning: Mengaitkan Konsep dan Prinsip Fisika dengan Nilai-Nilai Karakter, Sikap Sosial, dan Sikap Spiritual, Universitas Pendidikan Ganesha, 2016.

[17] I. W. Subagia, I. G. L. Wiratma, Evaluasi Penerapan Model Siklus Belajar Berbasis Tri Pramana Pada Pembelajaran Kimia di SMA, J. Pendidik dan Pengajaran, vol. 42, 2009, pp. 89-96.

[18] Alexon, N. S. Sukmadinata, Pengembangan Model Pembelajaran Terpadu Berbasis Budaya Untuk Meningkatkan Apresiasi Siswa Terhadap Budaya
Lokal, J. Cakrawala Pendidik, vol. 2, 2010, pp. 189203. DOI: https://doi.org/10.21831/cp.v2i2.339.

[19] I. W. Subagia, I. G. L. Wiratma, Taksonomi Pembelajaran dan Penilaian Hasil Belajar Berbasis Tri Kaya, JPI J. Pendidik. Indones. vol. 1, 2015, pp. 40-64. DOI: https://doi.org/10.23887/jpiundiksha.v1i1.4485. 